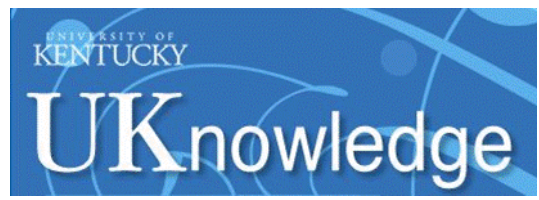

University of Kentucky

UKnowledge

Biosystems and Agricultural Engineering Faculty Publications

4-2015

\title{
Creating a National Coalition to Address Tractor Overturn Fatalities.
}

\author{
Pamela J. Tinc \\ Northeast Center for Occupational Health and Safety in Agriculture, Forestry, and Fishing \\ Paul D. Ayers \\ University of Tennessee \\ John J. May \\ Northeast Center for Occupational Health and Safety in Agriculture, Forestry, and Fishing \\ Mark A. Purschwitz \\ University of Kentucky, purschwitz@uky.edu \\ Julie A. Sorensen \\ Northeast Center for Occupational Health and Safety in Agriculture, Forestry, and Fishing
}

Follow this and additional works at: https://uknowledge.uky.edu/bae_facpub

Part of the Bioresource and Agricultural Engineering Commons

Right click to open a feedback form in a new tab to let us know how this document benefits you.

\section{Repository Citation}

Tinc, Pamela J.; Ayers, Paul D.; May, John J.; Purschwitz, Mark A.; and Sorensen, Julie A., "Creating a National Coalition to Address Tractor Overturn Fatalities." (2015). Biosystems and Agricultural Engineering Faculty Publications. 11.

https://uknowledge.uky.edu/bae_facpub/11

This Article is brought to you for free and open access by the Biosystems and Agricultural Engineering at UKnowledge. It has been accepted for inclusion in Biosystems and Agricultural Engineering Faculty Publications by an authorized administrator of UKnowledge. For more information, please contact UKnowledge@lsv.uky.edu. 


\section{Creating a National Coalition to Address Tractor Overturn Fatalities.}

Digital Object Identifier (DOI)

http://dx.doi.org/10.13031/jash.21.10745

Notes/Citation Information

Published in Journal of Agricultural Safety and Health, v. 21, no. 2, p. 105-112.

(c) 2015 ASABE

The copyright holders have granted the permission for posting the article here. 


\title{
Creating a National Coalition to Address Tractor Overturn Fatalities
}

\author{
P. J. Tinc, P. D. Ayers, J. J. May, M. A. Purschwitz, J. A. Sorensen
}

ABSTRACT. Tractor overturns continue to be the leading cause of death on U.S. farms. While rollover protective structures (ROPS) are effective in preventing these fatalities, they are underutilized due to a number of barriers. Past programs in the U.S. and abroad have targeted this area of agricultural safety; however, a national program is not yet in place for U.S. farmers. This study seeks to build a national partnership to address tractor overturn fatalities by increasing the number of tractors with ROPS. A diverse, multisector steering committee has been organized and is working together using Whole System in a Room methods. This method brings together partners from nine stakeholder groups to identify and commit to a collaborative solution to the issue.

Keywords. Collaboration, Partnership, ROPS, Tractor overturn, Whole system in a room.

$\mathrm{E}$ very day, farmers face a myriad of risks that can lead to injury or death. Agriculture accounts for approximately $70 \%$ of the fatalities included in the agriculture, fishing, and forestry sector (Murphy et al., 2010). In 2012, this sector (with the addition of hunting) had the highest fatality rate of all occupations, 22.8 per 100,000 workers, and the third highest number of fatalities, 509 (BLS, 2014). These statistics clearly demonstrate that agriculture continues to be one of the most dangerous occupations in the U.S.

Within agriculture, the highest risk of fatality is from tractor rollovers (CDC, 2013). Between 1992 and 2005, 1,412 farm workers died as a result of tractor overturns (NIOSH, 2009). Although overturn fatalities are preventable with the proper use of rollover protective structures (ROPS), which are available as roll bars or cabs and include seatbelts, only $51 \%$ to $59 \%$ of tractors in the U.S. are estimated to be equipped with ROPS (Loringer and Myers, 2008; Murphy et al., 2010). ASAE Standard S383.1 (and currently SAE J1194:1994) recommended that new tractors be equipped with ROPS (ASAE, 2004); however, ROPS were not provided as standard equipment until 1985 (Job, 2008) and are not available for many tractors built before 1970 (Hallman, 2005).

Loringer and Myers (2008) determined that factors such as farm size, operator age,

Submitted for review in April 2014 as manuscript number JASH 10745; approved for publication by the Ergonomics, Safety, \& Health Community of ASABE in January 2015.

The authors are Pamela J. Tinc, Research Coordinator, Northeast Center for Occupational Health and Safety in Agriculture, Forestry, and Fishing, Cooperstown, New York; Paul D. Ayers, ASABE Member, Professor, Department of Biosystems Engineering and Soil Science, University of Tennessee, Knoxville, Tennessee; John J. May, Deputy Director, Northeast Center for Occupational Health and Safety in Agriculture, Forestry, and Fishing, Cooperstown, New York; Mark A. Purschwitz, ASABE Member, Extension Professor, Department of Biosystems and Agricultural Engineering, University of Kentucky, Lexington, Kentucky; Julie A. Sorensen, Director, Northeast Center for Occupational Health and Safety in Agriculture, Forestry, and Fishing, Cooperstown, New York. Corresponding author: Pamela Tinc, NEC, 1 Atwell Road, Cooperstown, NY 13326; phone: 607-547-6023; e-mail: pam.tinc@bassett.org.

Journal of Agricultural Safety and Health

21(2): 105-112 C 2015 ASABE ISSN 1074-7583 DOI 10.13031/jash.21.10745 
annual farm income, and whether the farm is a full-time or part-time operation are significant predictors of ROPS prevalence on U.S. farms. In addition, general economic concerns, ROPS interference with farm tasks, and beliefs related to farm safety and the necessity of ROPS have been identified as barriers to retrofitting (Hard and Myers, 2011).

In the past, there have been a number of attempts to increase the use of ROPS on farms. For example, Kentucky researchers stimulated an increase in ROPS prevalence with a combination of education and community promotion (Cole and Myers, 2002). Rebate and cost-savings programs have also been used successfully, both alone and in conjunction with other efforts. Outside the U.S., multi-faceted programs, including publicity, rebates, and regulation, effectively placed a high number of ROPS kits on farms in multiple Australian states, including Victoria (Day et al., 2003; Day and Rechnitzer, 2006; Franklin et al., 2006). Within the U.S., rebate programs in New York, Virginia, and North Carolina have been successful in providing ROPS kits to local farmers (Extension, 2012).

The 2004 NIOSH Tractor Safety Initiative, a collaboration between the ten NIOSH Agricultural Safety and Health Centers, was created to address tractor overturn fatalities at the national level (Swenson, 2004). The initiative, which was in part designed to "establish a range of incentives to retire older tractors or retrofit them with ROPS," determined that a necessary component of a national ROPS program is to reduce the financial burden of installing ROPS kits (Swenson, 2004). The program was to be led by partners from each of the NIOSH Agricultural Centers in a steering committee known as the Initiative Leadership Council and include stakeholders from other organizations in the Interested Party Network (Swenson, 2004).

In 2005, the Tractor Safety Initiative was funded, for two years, and led by researchers at the High Plains Intermountain Center for Agricultural Health and Safety (HICAHS, 2007). This effort included research on the cost of overturn fatalities and injuries, ROPS policy, financial incentives, and social marketing of ROPS (HICAHS, 2007). Around the same time, an effort by the New York Center for Agricultural Medicine and Health (NYCAMH) to establish a social marketing campaign to promote ROPS was also funded (HICAHS, 2007; Sorensen et al., 2009). This program involved the use of tailored messages and rebates to encourage tractor owners and operators to retrofit their tractors with ROPS (HICAHS, 2007; Sorensen et al., 2009).

The Tractor Safety Initiative used information from the New York ROPS program and its own results to develop its recommendations. These recommendations included: (1) developing a national agricultural tractor safety public health campaign, (2) using regional programs in high-risk areas to build a national ROPS rebate program, (3) ensuring a stable distribution system for ROPS, (4) identifying funds and providing financial incentives for ROPS retrofitters, and (5) using a social marketing campaign to persuade farmers to retrofit their tractors (HICAHS, 2007). Although the Tractor Safety Initiative ended in 2007, the New York ROPS program was continued.

In 2010, the promise of rebate programs was highlighted by the former director of the NIOSH Agriculture, Forestry, and Fishing Program, George Conway, who described the New York program as "successfully combining a rebate program for retrofitting older tractors with a very persuasive social marketing campaign" (Conway, 2010).

Over the past decade, the proportion of tractors with rollover protection has inched upward, leading to anticipation that this problem will resolve itself in the foreseeable future. In the meantime, however, without intervention, the farm community will sustain hundreds of preventable deaths and many more disabling injuries. Further, a review of 
the overturn fatality data reveals geographic differences, with the highest rates of overturn incidents occurring where hazardous topography coincides with strained farm economics. Despite national trends favoring ROPS use, without financial assistance, thousands of farmers in these regions will continue to experience excessive risk of overturn injury and fatality.

Although considerable research has been conducted on identifying various means of increasing the number of ROPS-protected tractors, the development of a national ROPS strategy that builds on previous ROPS efforts, including the NIOSH Tractor Safety Initiative, could greatly advance U.S. tractor safety efforts. In this article, we discuss the necessary components of a national ROPS program and the research efforts for developing the necessary resources for providing these components. The research efforts that will be described mainly involve development of a multi-sector collaboration that will leverage the resources necessary to create a large-scale, national ROPS rebate program.

\section{Components of a National ROPS Program}

\section{Administrative Support}

Based on the experiences of existing ROPS programs, extensive administrative support would be needed to process requests for logistical and financial assistance for ROPS installations. This administrative support would likely include both a web-based ordering system as well as a telephone hotline for tractor owners to call. Both of these components would address concerns related to the efforts required of farmers to identify, locate, price, and order the correct ROPS system for a specific tractor, making these critical program features (Hallman, 2005; Sorensen et al., 2009). A web-based system similar to the one described above has been created by the Southeast Center for Agricultural Health and Injury Prevention (University of Kentucky, 2010). This online ROPS guide and identification system provides basic information about ROPS kits, allows users to view available ROPS kits for common tractor models, and provides some dealer information (University of Kentucky, 2010). In addition to guiding farmers through the identification and purchase of ROPS kits, the administrative team would also be required to ensure completion of ROPS installation and subsequent rebate processing.

\section{Rebate Funding}

In addition to logistical challenges, the high costs of ROPS tend to discourage farmers from installation; however, rebates can significantly reduce the financial burden. In past and current programs, rebates have played an important role in encouraging farmers to retrofit their tractors. Thus, in addition to administrative support, funding would be needed for rebates and incentives to encourage retrofitting. It is likely that rebate funds would have to be obtained through extensive fundraising efforts for each state or region.

While rebates have been successful incentives in the past, the cost of ROPS kits, from both after-market and original equipment manufacturers, has increased over the last few years, deterring some farmers from purchasing (Sorensen et al., 2013a). In five states with ROPS rebate programs, 112 farmers who had requested quotes (out of 4,508 total) did not follow through with retrofitting because, despite available rebates of up to $\$ 865$, out-of-pocket costs for ROPS kits were still "too expensive." Another 45 farmers cited "financial timing" as their reason for not proceeding with the retrofit. To alleviate some of the cost-related barriers, it may be necessary to secure additional funding per ROPS, or 
work with manufacturers to reduce the prices of ROPS kits.

\section{ROPS Supply}

ROPS supply could be another significant challenge to implementing a national campaign. It is estimated that approximately 3,961,000 tractors are present on U.S. farms, and that between 1,624,010 and 1,940,890 of them do not have ROPS kits installed (Loringer and Myers, 2008; Murphy et al., 2010). Because nearly every tractor model requires a different ROPS design, bulk inventory is generally not available. It is imperative that manufacturers are prepared for increased ROPS sales to prevent farmers from becoming discouraged with backordered kits and lengthy processing. By knowing the tractor model distribution of previous ROPS retrofits, a strategic ROPS supply can be generated as the national ROPS program begins. Table 1 shows the ten most common tractors (without ROPS installed) found on farms in the U.S., as well as the ten tractors that are most often requested to be retrofitted through the Northeast ROPS program.

\section{Promotion}

Promotion efforts are an essential part of a ROPS program. Not only does promotion serve to educate populations who might not realize the danger of tractor rollovers, it also plays a role in encouraging farmers to retrofit. In the past, print advertisements tailored to farm populations have been used to persuade farmers to practice safe farming. It is likely that this method of promotion could again be successful. Further, promotions that provide additional incentives (e.g., a Carhartt jacket) to retrofitters could lead to increased success. It is likely that promotion budgets will be quite high at the beginning of a national ROPS program, but will be reduced once the program is established.

\section{Building a National Coalition}

In order to create and implement a national ROPS program, collaborative relationships must be established. This sentiment is echoed in the NIOSH National Occupational Research Agenda (NORA), which underscores the importance of collaborations, as well as the process of building and maintaining collaborations (NORA, 2008). The NORA goal involves increasing the reach of health and safety strategies to a greater number of workplaces by using collaborative partnerships to provide resources and support.

In the past, farm safety efforts have failed because stakeholders were not adequately involved in the decision-making process. It has been argued that insufficient stakeholder support contributed to the recent failure of proposed legislation for child labor in agricul-

Table 1. The most common tractors found on U.S. farms without installed ROPS, and the tractors for which ROPS retrofits are most commonly requested through the Northeast ROPS program.

\begin{tabular}{cc}
\hline $\begin{array}{c}\text { Most common tractors on U.S. farms } \\
\text { without ROPS kits installed }{ }^{[\mathrm{a}]}\end{array}$ & $\begin{array}{c}\text { Most Commonly Requested } \\
\text { John Deere D }\end{array}$ \\
Ford/New Holland 2N/8N/8NAN/9N & John Deere 4020 \\
John Deere 4020 & John Deer 3020 \\
Ford 8N \\
International/Case 140/Farmall 140 & Ford 5000 \\
Ford/New Holland Country British Ford 1884 & International 1066 \\
International/Case Farmall C & Ford 4000 \\
John Deere 3020 & John Deere 3010 \\
Ford/New Holland 3000 & John Deere 4010 \\
Ford/New Holland 4000 & John Deere 4320 \\
Massey Ferguson A & International 656
\end{tabular}


ture (Miller, 2012; Richardson, 2012; USDOL, 2012). For a ROPS initiative to avoid a similar fate, all stakeholders must be invited to the table, and their input must be welcomed and considered.

\section{Building a Multi-Sector ROPS Initiative}

\section{Social Networking Analysis}

One of the biggest challenges that researchers face in creating extensive and encompassing collaborations is identifying the most invested and appropriate partners. To move forward in expanding ROPS programs, researchers at the Northeast Center for Occupational Health and Safety in Agriculture, Forestry, and Fishing used social networking analyses to identify key collaborators for a National Tractor Safety Coalition (NTSC) (Sorensen et al., 2013b). This method involved surveying agricultural organizations to identify stakeholders who have the necessary resources and interest to support a national initiative. Organizations were also asked to identify stakeholders who are viewed positively by other organizations and the farm community, and who have a demonstrated interest in tractor safety. The identified stakeholders were then surveyed to enumerate the degree to which they were connected to other organizations in the agricultural community. Preference was given to organizations that had a centralized, well-connected role in the stakeholder network.

\section{National Tractor Safety Coalition (NTSC)}

As a result of the social networking analysis, twelve organizations were identified as key partners in agricultural health and safety and were invited to participate in the NTSC Steering Committee. Composed of researchers, health and safety organizations, insurance companies, financial institutions, manufacturer representatives, and other agricultural organizations, the NTSC seeks to fulfill the following mission: "To prevent tractorrelated injuries and deaths in U.S. agriculture by developing and implementing collaborative, stakeholder-driven, evidence-based solutions."

Since June 2013, the NTSC Steering Committee has met monthly via teleconference and has conducted one in-person meeting. During the monthly calls, the group discusses relevant issues, allowing all participants to voice their opinions in a safe and open environment. For topics that are left unresolved at the end of the meeting, members can provide their opinions to the organizing researchers, and decisions are made based on majority interest.

\section{Getting the Whole System in the Room}

During the initial meetings, the Steering Committee identified the need for a larger collaboration and additional resources in order to address tractor rollovers at a national level. Members have also acknowledged the need to ensure an adequate ROPS supply, which would require a concerted effort from ROPS and tractor manufacturers. As a result, a whole-systems approach was identified as a method of rallying a larger consortium of organizations for this endeavor. Ideally, this approach would allow for the partnership to gain support and resources from organizations and individuals across multiple sectors.

The Whole System in a Room (WSR) methodology was developed by Future Search Network, a collaboration of volunteers who provide planning workshops to non-profit, non-governmental, and community organizations at low cost (Future Search, 2014a). Such events involve bringing together diverse stakeholder groups that have the potential 
to contribute to a solution (Weisbord and Janoff, 2007). The basic tenet of WSR is that all members of a system should be involved in the decision-making and strategy implementation process. Through this process, organizations are invited to participate in a two to three day workshop at which they discuss the past, present, and future of an issue to identify common ground and a strategy for moving forward. Throughout the event, participants from each stakeholder group engage in small group discussions to work through the issues before collaborating with the group as a whole. At the end of the workshop, participants are asked to commit to actions, on behalf of their parent organizations, that will contribute to change and to the common goals of the group (Future Search, 2014b). Upon completion of the event, goals and action plans will be reviewed periodically (e.g., at three, six, twelve month intervals) with participants to ensure progress is made. Progress is often defined as the completion of action items, by partners, after the workshop.

In order to address tractor rollovers, the NTSC has invited 81 organizations across nine stakeholder groups to participate in a two-day WSR workshop and the NTSC. These stakeholder groups were formed based on primary organizational function and include:

- Manufacturers

- Agriculture organizations

- Farm safety advocates

- Researchers

- Health and safety organizations

- Financial and insurance groups

- Government organizations

- Private corporations

- Media.

While the overall goal of the WSR workshop is to encourage stakeholders to identify common ground and begin working toward a national ROPS program, the goals related to the program itself are identified collaboratively by workshop participants. Through the WSR process, each stakeholder group will identify tasks that they can accomplish to contribute to the creation of a national ROPS program. Results of the WSR workshop will be published at a later time.

\section{Conclusions}

Tractor rollovers remain the leading cause of work-related death on farms; therefore, it is imperative that this issue be addressed at a national level. The experience of the recently proposed agricultural child labor law suggests that extensive and collaborative partnerships are necessary to facilitate lasting solutions in the farm community. The National Tractor Safety Coalition and the Whole System in a Room process aim to build these partnerships and develop a sustainable ROPS program in order to reduce the number one work-related killer of farmers: tractor rollovers.

\section{Acknowledgements}

The authors would like to thank the National Institute for Occupational Safety and Health for support of this project (Grant No. 5R21OH009796-02), as well as the members of the National Tractor Safety Coalition for their contributions to this project. Additionally, the authors wish to thank Patrick Papania and Bithiah Lafontant of FHI 360 for their collaboration and support throughout the Whole System in a Room process. 


\section{References}

ASAE. (2004). S383.1: Rollover protective structures (ROPS) for wheeled agricultural tractors. St. Joseph, Mich.: ASAE.

BLS. (2014). Census of fatal occupational injury charts, 1992-2012: Preliminary data. Washington, D.C.: Bureau of Labor Statistics. Retrieved from http://stats.bls.gov/iif/oshwc/cfoi/cfch0011.pdf.

CDC. (2013). Agricultural safety. Atlanta, Ga.: Centers for Disease Control and Prevention. Retrieved from www.cdc.gov/niosh/topics/aginjury/.

Cole, H. P., \& Myers, M. (2002). The Kentucky ROPS project: A summary. Lexington, Ky.: University of Kentucky. Retrieved from www.mc.uky.edu/scahip/ropsnotebook.html.

Conway, G. (2010). Retrofitting roll bars and seatbelts for old U.S. tractors to prevent farm deaths: Now or never. J. Agric. Safety and Health, 16(1), 3-5. http://dx.doi.org/10.13031/2013.29250.

Day, L., \& Rechnitzer, G. (2006). Evaluation of the tractor rollover protective structure rebate scheme 1997/98. Report No. 155. Melbourne, Australia: Monash University Accident Research Center.

Day, L., Rechnitzer, G., \& Lough, J. (2003). An Australian experience with tractor rollover protective structure rebate programs: Process, impact, and outcome evaluation. Accident Analysis and Prevention, 36(5), 861-867. http://dx.doi.org/10.1016/j.aap.2003.09.001.

Extension. (2012). Aftermarket ROPS rebate programs. Centreville, Ala.: Extension Foundation. Retrieved from www.extension.org/pages/64350/aftermarket-rops-rebate-programs.

Franklin, R. C., Stark, K.-L., \& Fragar, L. (2006). Intervention strategies for the retro-fitment of rollover protective structures (ROPS) and fleet characteristic, farm tractors. Safety Sci., 44(9), 771783. http://dx.doi.org/10.1016/j.ssci.2006.04.002.

Future Search. (2014a). Introducing the Future Search network. Philadelphia, Pa.: Future Search Network. Retrieved from http://futuresearch.net/network/whatis/index.cfm.

Future Search. (2014b). Future Search methodology. Philadelphia, Pa.: Future Search Network. Retrieved from http://futuresearch.net/method/methodology/index.cfm.

Hallman, E. M. (2005). ROPS retrofitting: Measuring effectiveness of incentives and uncovering inherent barriers to success. J. Agric. Safety and Health, 11(1), 75-84. http://dx.doi.org/10.13031/2013.17898.

Hard, D. L., \& Myers, J. R. (2011). Adoption of rollover protective structures (ROPS) on U.S. farm tractors by state: 1993-1995, 2001, and 2004. J. Agric. Safety and Health, 17(2), 157-172. http://dx.doi.org/10.13031/2013.36499.

HICAHS. (2007). National agricultural tractor safety initiative: Final progress report and recommendations. Fort Collins, Colo.: High Plains Intermountain Center for Agricultural Safety and Health. Retrieved from www.hicahs.colostate.edu/documents/12-21-07_Final_TSI_Rept.doc.

Job, R. W. (2008). Rollover protective structure development: An industry perspective. ASABE Paper No. 083751. St. Joseph, Mich.: ASABE.

Loringer, K. A., \& Myers, J. R. (2008). Prevalence of ROPS-equipped tractors on U.S. farms, 2001 and 2004. J. Safety Res., 39(5), 509-517. http://dx.doi.org/10.1016/j.jsr.2008.08.003.

Miller, M. E. (2012). Historical background of the child labor regulations: Strengths and limitations of agricultural hazardous occupations orders. J. Agromed., 17(2), 163-185. http://dx.doi.org/10.1080/1059924X.2012.660434.

Murphy, D. J., Cavaletto, R., May, J., McKenzie, E. A., Myers Jr., J., \& Sorensen, J. (2010). Tractors and rollover protection in the United States. J. Agromed., 15(3), 249-263. http://dx.doi.org/10.1080/1059924X.2010.484309.

NIOSH. (2009). Preventing death and injury in tractor overturns with rollover protective structures. Atlanta, Ga.: Centers for Disease Control and Prevention. Retrieved from http://blogs.cdc.gov/niosh-science-blog/2009/01/05/rops/.

NORA. (2008). National agriculture, forestry, and fishing agenda. Washington, D.C.: NIOSH, National Occupation Research Agenda. Retrieved from www.cdc.gov/niosh/nora/comment/agendas/agforfish/pdfs/AgForFishDec2008.pdf.

Richardson, P. (2012). Rural kids, parents angry about Labor Dept. rule banning farm chores. The 
Daily Caller (25 April 2012). Retrieved from http://dailycaller.com/2012/04/25/rural-kids-parentsangry-about-labor-dept-rule-banning-farm-chores/?print=1.

Sorensen, J. A., Einehall, L., Lehmen, T., May, J., Ostby-Malling, R., Stenlund, H., Strand, J., \& Emmelin, M. (2009). Encouraging the installation of rollover protective structures in New York State: The design of a social marketing intervention. Scandinavian J. Public Health, 37(1), 859869.

Sorensen, J. A., Bayes, B., Jenkins, P. L., Madden, E., Purschwitz, M. A., \& May, J. J. (2013a). Increases in ROPS pricing from 2006-2012 and the impact on ROPS demand. J. Agric. Safety and Health, 19(2), 115-124. http://dx.doi.org/10.13031/jash.19.9971.

Sorensen, J. A., Brewer, D., Wyckoff, L., \& Horsman, M. (2013b). Building safety partnerships using social network analysis. Social Marketing Qtly., 19(2), 67-75. http://dx.doi.org/10.1177/1524500413483457.

Swenson, E. (Ed.). (2004). National agricultural tractor safety initiative. Seattle, Wash.: University of Washington, Pacific Northwest Agricultural Safety and Health Center.

University of Kentucky. (2010). The Kentucky ROPS guide. Lexington, Ky.: Southeast Center for Agricultural Health and Injury Prevention. Retrieved from http://warehouse.ca.uky.edu/rops/ropsinstrotherinfo.asp.

USDOL. (2012). Labor Department statement on withdrawal of proposed rule dealing with children who work in agricultural vocations. Washington, D.C.: U.S. Department of Labor. Retrieved from www.dol.gov/whd/media/press/whdpressVB3.asp?pressdoc=national/20120426.xml.

Weisbord, M., \& Janoff, S. (2007). Get the whole system in the room. J. Qual. Participation, 30(3), 48. 